\title{
Herbal extracts and essential oils microencapsulation studies for different applications
}

\author{
Euridice Ladisu Mejía-Argueta $^{(\mathbb{1}}$, Jonnathan Guadalupe Santillán-Beníte ${ }^{{ }^{*}}{ }^{\mathbb{D}}$, Miriam V. Flores-Merino $^{2}$, \\ Claudia Cervantes- Rebolledo ${ }^{3}$ \\ ${ }^{1}$ Autonomous University of the State of Mexico (UAEMex) Faculty of Chemistry. Toluca, Mexico. Toxicology Laboratory, Pharmacy Department, Faculty \\ of Chemistry, UAEMex. Zipcode: 50120 \\ ${ }^{2}$ Autonomous University of the State of Mexico (UAEMex) Faculty of Chemistry. Toluca, Mexico. Molecular and Cell Biology Laboratory, Faculty of \\ Chemistry, UAEMex. Zipcode: 50120 \\ ${ }^{3}$ UICUI. University of Ixtlahuaca. Ixtlahuaca, State of Mexico. Zipcode: 50740
}

\section{A R T I C L E I N F O}

Article Type:

Mini Review

Article History:

Received: 11 March 2021

Accepted: 10 May 2021

\section{Keywords:}

Biomaterials

Essential oil

Herbal extracts

Microencapsulation methods

Natural compounds

\begin{abstract}
A B S T R A C T
Studies on bioactivities of numerous essential oils (EOs) and herbal extracts compounds against diseases are crucial. Microencapsulation methods development might be an alternative to obtain bioactive compounds for cosmetics and pharmaceutical uses. In this study, we carried out a literature review of 219503 data articles using ScienceDirect, Redalyc, Web of Science, Scopus, SciELO, and Google Scholar databases in English and Spanish, after with inclusion (original articles, book chapters, and theoretical references) and exclusion criteria (frameworks description), we found 1854 restricting the publication years between 2004 and August 2020 and 35 relevant articles with our scope research. References found contained a collection of methods that could be utilized to create microcapsules, including coacervation, extrusion, polymerization, and spray drying. This article analyzed the most recent and advanced microencapsulation techniques and their applications in the food, cosmetic, and pharmaceutical industries. Herbal extracts and EOs have many applications, depending on the wall materials and microencapsulation methods that could help know about selective release and efficacy to ensure optimal dosing and other advantages; thus, improving the profitability of these product manufacturers.
\end{abstract}

Implication for health policy/practice/research/medical education:

This mini-review gathers evidence about different applications of herbal microencapsulations in cosmetic, food, and pharmaceutical industries, and diverse methods to obtain microspheres with their characteristics, wall materials, principles actives to protect, and applications in the available literature.

Please cite this paper as: Mejía-Argueta EL, Santillán-Benítez JG, Flores-Merino MV, Cervantes-Rebolledo C. Herbal extracts and essential oils microencapsulation studies for different applications. J Herbmed Pharmacol. 2021;10(3):289-295. doi: 10.34172/ jhp.2021.33.

\section{Introduction}

Microencapsulation is a technique that protects bioactive compounds against physicochemical conditions (i.e., oxidation, light, temperature, etc.), instability in various solvents, and volatile loss (1). Yeşilsu and Özyurt showed better oxidative stability in fish oil microencapsulated with herbal extracts than other commercial antioxidants. This phenomenon was determined by the fish oils exposed to high temperatures (i.e., $23^{\circ} \mathrm{C}, 40^{\circ} \mathrm{C}$, and $60^{\circ} \mathrm{C}$ ) and evaluated with natural and commercial antioxidants using peroxide formation kinetics (2). Other studies demonstrated that thermal stability increased with microencapsulation of garlic oil or other products, such as essential oil (EO) extracted from bell pepper $(3,4)$. Furthermore, this microencapsulation also regulates the EO extract's release rate, keeping it at appropriate concentrations to produce the desired antimicrobial effect at a specific location to allow its metabolic absorption. Several techniques have been used for microencapsulation. Some examples are molecular inclusion polymeric micelles, freeze-drying, spraydrying, extrusion processes, liposomes, coacervation, nanostructured lipid matrices, supercritical fluids, and solvent evaporation (5). Size reduction leads to an increased 
surface area, providing constant drug concentration in blood, decreasing dose and toxicity, and providing better drug utilization. The latter will improve bioavailability and reduce adverse effects incidence or intensity, protecting the gastrointestinal tract from the drug's irritant effects, reducing the core's reactivity concerning the outside environment. On the other hand, there are increasing processing costs compared with standard formulations; less likely to be reproducible, and process conditions $(\mathrm{pH}$, stability, temperature) change (6).

EOs exist in plants extracted by hydrodistillation or simple distillation containing terpenes, esters, aldehydes, ketones, and phenols, ethers, and other compounds (7). Their composition depends on the type of plant and the species. These compounds are frequently used for other purposes such as antifungal, antiviral, antioxidant, antibacterial, and anti-inflammatory activities. For example, the EO of Origanum vulgare has a broad spectrum effects such as growth inhibition against bacteria and fungi, antioxidant, antifungal, antiviral, and anti-inflammatory activities (8). Moreover, Cremaspora triflora, Maesa lanceolate, Hypericum roeperianum, and Elaeodendron croceum extracts had growth inhibition in E. coli, E. faecalis, and S. typhimurium (9).

Encapsulation is a suitable method for protecting sensitive and unstable materials of herbal extracts and EOs. The main advantages of plant use include a novel herbal formulation, less toxicity, improved solubility, bioavailability enhancement, protection from degradation, drug release control, improved stability, and better therapeutic efficiency (10).

Other studies demonstrated the efficacy of extracts or EOs microencapsulation. A study showed that erythromycin, bacitracin microencapsulated into the Lycopodium clavatum sporopollenin provided better gastrointestinal release, bioavailability, and enhanced antibacterial activity (11).
This literature compilation is of the utmost importance given that consumer demand for natural products has increased to a greater extent due to the preference for ecofriendly and additive-free products. The latter requires new research venues to explore possible future implications for industry, academia, and consumers. Therefore, it is vital to explore the EOs' characteristics, limitations, and potential to analyze their physicochemical pros and cons. Thus, in this review, we present essential microencapsulation techniques that can be used to increase stability and the use of natural products and their applications, materials involved in the manufacturing process, chemical techniques like microspheres, among other analyses.

\section{Methods}

We searched literature in order to perform this analysis. We collected relevant literature using ScienceDirect, Redalyc, Web of Science, Scopus, SciELO, and Google Scholar databases in English and Spanish, restricting the publication years between 2004 and August 2020 (Figure 1).

\section{Eligibility criteria}

References were filtered using search terms in the title or summary, including the following keywords (and all their combinations): microencapsulation types, microencapsulation methods, microencapsulation of EOs. The search was performed in original articles, book chapters, and theoretical references (i.e., reviews, minireviews, surveys).

Exclusion criteria

After applying the aforementioned inclusion criteria, we retrieved articles by reading their titles, abstracts, and methodological frameworks description. We then excluded papers consisting of conference proceedings, commentaries, thesis, and technical reports. Also, we

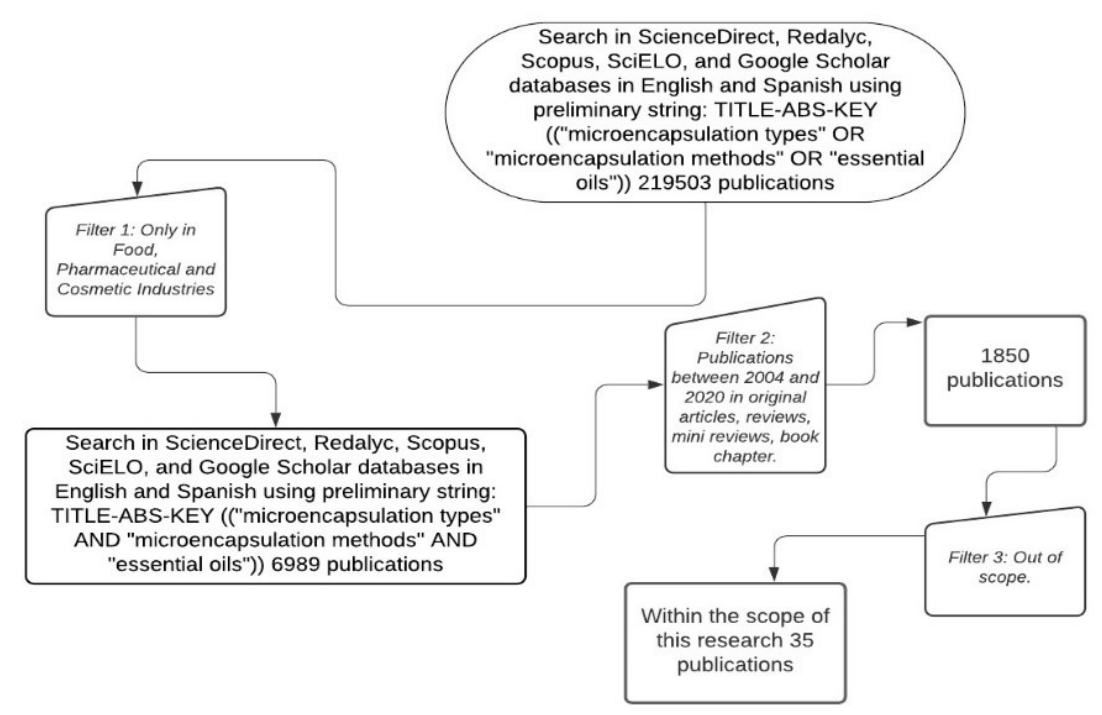

Figure 1. Representation of the research process. 
compared papers written by the same authors to remove duplicated documents.

\section{Data extraction}

The following information was extracted to address the literature review: microencapsulation techniques, microspheres, medicinal plant compounds, additives, and applications in the pharmaceutical industry, food industry, cosmetic industry, natural extracts, and EOs, which helped delimit which articles to use. Particular interest was given to the advantages, extraction methods, types of microspheres, and applications in the pharmaceutical, food, and cosmetic industries.

\section{Data visualization}

We continued our data mining by using a computerized analysis using the VOSviewer computer program and found 219,503 data records on ScienceDirect, Redalyc, Web of Science, Scopus, SciELO, and Google Scholar databases in English and Spanish for the VOSviewer data mining. We used 100 articles as the top relevant keywords, and considered this data set as a representative sample.

\section{Results}

In the last years, the importance of encapsulation has grown because it is a technology that offers the delivery of bioactive compounds in several industries (i.e., pharmaceutical), compounds protection, and controlled and targeted release. In this work, we provided a summary based on 35 academic articles reviewed. We described the most frequent microencapsulation methods, mentioning how they were performed, the conditions, applications, and the carriers used. Finally, we showed the most used microspheres, their function, advantages, examples of materials used, and their production method. The VOSviewer data mining showed the main keywords and we could visualize that the main fields were found in words "essential oils, antimicrobial agents, microencapsulation and chemical composition," in addition to other words related to each field (Figure 2).

\section{Microencapsulations types}

Spray drying technique has low cost and is readily available equipment. Hence, it is the most common technology used in industry (12). The method to obtain dry solid particles is by hot air, which dries the liquid droplets (solution, emulsion, or suspension) produced in the drying chamber. Encapsulating agents usually save their physicochemical properties (13). In addition, depending on the core material and the desired characteristics for the final product, carrier materials preserve substances against adverse temperature, $\mathrm{pH}$, and humidity conditions. Other components that react with the protected material, i.e., starch or carbohydrates, can be selected from a wide variety of natural and synthetic polymers (14).

The microencapsulation types used to encapsulate active

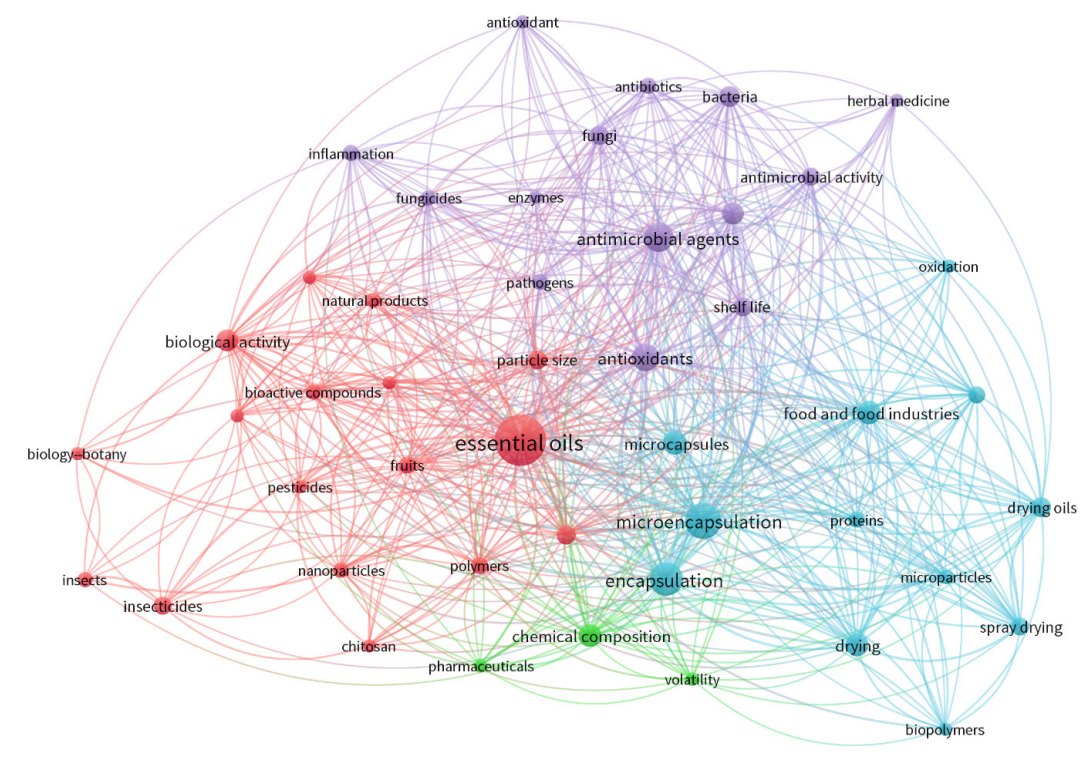

Figure 2. Top 100 most relevant data articles of herbal' microencapsulation methods. The most prominent terms in this study included EOs with 79 , microencapsulation with 37, encapsulation with 31, antimicrobial agents with 24, and antioxidants with 22 occurrences. Each cluster represents prevalent research themes in decreasing order. The first cluster is EOs (red-color), comprised of 14 words. The aggregated terms connote the main criteria on EOs with their composition (natural and bioactive compounds) with different formulations (nanoparticles, polymers, chitosan) in applications as insecticides or with biological activity. The second cluster is antimicrobial agents (purple color) with 13 relevant words. The cluster alludes to publications that reveal biological activities of herbal medicines as antibiotics, enzymes, antioxidants, fungicide, and inflammation. The third cluster is microencapsulation (blue-color) with ten relevant words. These words cumulatively suggest different microencapsulation methods (biopolymers, drying oils, microcapsules, microparticles, spray drying). The fourth cluster is chemical composition (green-color) with three relevant words about volatility and pharmaceutical applications. 
Mejía-Argueta et al

Table 1. Microencapsulation types and their characteristics

\begin{tabular}{|c|c|c|c|c|}
\hline $\begin{array}{l}\text { Types of } \\
\text { microencapsulation }\end{array}$ & Description & Conditions & Applications & Carrier \\
\hline $\begin{array}{l}\text { Complex } \\
\text { coacervation }\end{array}$ & $\begin{array}{l}\text { The capsule is formed by } \\
\text { the ionic interaction of two } \\
\text { oppositely charged polymers, } \\
\text { commonly positive charges on } \\
\text { protein molecules and anionic } \\
\text { macromolecules (15). }\end{array}$ & $\begin{array}{l}\text { Formation of three- } \\
\text { immiscible chemical phases. } \\
\text { Deposition of the coating. } \\
\text { Solidification of the layer } \\
\text { (15). }\end{array}$ & $\begin{array}{l}\text { Food and } \\
\text { pharmaceutical } \\
\text { industries to } \\
\text { encapsulate } \\
\text { bioactive } \\
\text { ingredients (16). }\end{array}$ & $\begin{array}{l}\text { Gelatin/gum arabic, } \\
\text { alginate/ polylysine, gelatin/ } \\
\text { carboxymethylce-llulose, } \\
\text { albumin/gum arabic, etc. (16). }\end{array}$ \\
\hline Simple coacervation & $\begin{array}{l}\text { The polymer competes for the } \\
\text { gelatin protein solution solubility } \\
\text { by hydrophobic interaction (17). }\end{array}$ & $\begin{array}{l}\text { Formation of immiscible } \\
\text { chemical phases. Coating } \\
\text { deposition. } \\
\text { Layer solidification (18). }\end{array}$ & $\begin{array}{l}\text { Encapsulation of } \\
\text { bacterial cells such } \\
\text { as yogurt (18). }\end{array}$ & $\begin{array}{l}\text { A non-solvent or a more } \\
\text { water-soluble polymer (i.e., } \\
\text { gelatin or ethylcellulose) (17). }\end{array}$ \\
\hline $\begin{array}{l}\text { Phase inversion } \\
\text { precipitation }\end{array}$ & $\begin{array}{l}\text { A de-mixing process in which the } \\
\text { initially homogeneous polymer } \\
\text { solution is transformed from } \\
\text { a liquid state to a solid state is } \\
\text { controlled (19). }\end{array}$ & $\begin{array}{l}\text { Membrane structure, } \\
\text { properties, and chemical } \\
\text { interaction depend on } \\
\text { polymer choice, as does the } \\
\text { selection of additives used } \\
\text { in the casting solution (19). }\end{array}$ & $\begin{array}{l}\text { Production of } \\
\text { nanoemulsions of } \\
\text { herbal products } \\
\text { (20). }\end{array}$ & $\begin{array}{l}\text { A polymer (i.e., polysulfone), } \\
\text { non-solvent, and solvent ( } 20) \text {. }\end{array}$ \\
\hline Centrifugal extrusion & $\begin{array}{l}\text { A liquid coextrusion process } \\
\text { utilized nozzles consisting of } \\
\text { a concentric orifice located } \\
\text { in a rotating cylinder's outer } \\
\text { circumference (21). }\end{array}$ & $\begin{array}{l}\text { The core mix in a coating } \\
\text { material separation. Pour } \\
\text { the mixture over a rotating } \\
\text { disc to obtain encapsulated } \\
\text { tiny particles. Drying (21). }\end{array}$ & $\begin{array}{l}\text { Food ingredients or } \\
\text { probiotic bacteria } \\
\text { microencapsulations } \\
(21) \text {. }\end{array}$ & $\begin{array}{l}\text { Gelatin, sodium alginate, } \\
\text { carrageenan, starches, } \\
\text { cellulose derivatives ( } 21) .\end{array}$ \\
\hline $\begin{array}{l}\text { Interfacial } \\
\text { polymerization }\end{array}$ & $\begin{array}{l}\text { A condensation polymerization } \\
\text { occurs at an interface between an } \\
\text { aqueous solution containing one } \\
\text { monomer and an organic solution } \\
\text { containing a second monomer } \\
(22) \text {. }\end{array}$ & $\begin{array}{l}\text { Polyamide layer formed in- } \\
\text { situ (22). }\end{array}$ & $\begin{array}{l}\text { EO encapsulation for } \\
\text { the healthcare and } \\
\text { cosmetic industry } \\
\text { (23). }\end{array}$ & $\begin{array}{l}\text { Thin-film composite } \\
\text { polyamide membranes (23). }\end{array}$ \\
\hline Spray drying & $\begin{array}{l}\text { Based on the mixture atomization } \\
\text { of the active substance and a } \\
\text { melted lipid. The material stays in } \\
\text { a cold chamber in which droplets } \\
\text { in contact with cool air solidify } \\
\text { to form solid lipid microparticles } \\
\text { that retain and protect the active } \\
\text { substance (24). }\end{array}$ & $\begin{array}{l}\text { Preparation, } \\
\text { homogenization, } \\
\text { atomization of the } \\
\text { dispersion, and dehydration } \\
\text { of the atomized particles } \\
\text { (24). }\end{array}$ & $\begin{array}{l}\text { Active ingredient } \\
\text { encapsulating such as } \\
\text { ascorbic acid (25). }\end{array}$ & $\begin{array}{l}\text { Modified starch, } \\
\text { maltodextrin, gum (25). }\end{array}$ \\
\hline
\end{tabular}

compounds or active pharmaceutical ingredients can be seen in Table 1. This table describes each method, conditions, and application in industries like the pharmaceutical or cosmetic industry.

Some of the various uses of microencapsulation in the industry are antimicrobial microencapsulates (i.e., chitosan microspheres), EOs encapsulation for controlled liberation (i.e., encapsulation with cyclodextrin), microspheres types, functions in turn to their composition, their production method, and their applications in pharmaceutical, cosmetic or food industries (see Table 2).

\section{Discussion}

EOs and plant origin extracts are commonly used as flavoring agents in food and beverages, pharmaceuticals, and cosmetic products for their antimicrobial and antioxidant properties $(8,9)$. Many factors affect their physicochemical compositions, hydrophobic nature, and density, often lower than water. EOs and plant extracts are generally lipophilic, soluble in organic solvents, and not miscible with water (9).

Several studies have suggested that EOs and herbal extracts' antimicrobial actions are attributed to their capacity to penetrate into the cells through bacterial membranes, inhibiting their functional activities $(9,11,30,31)$. This phenomenon is due to the Grampositive bacteria cell wall structure, which allows hydrophobic molecules to penetrate the cells and act on both the cell wall and the cytoplasm (32).

The phenolic nature of EOs is involved in interfering with enzymes involved in energy production. At higher concentrations, they can denature proteins, which also cause an antimicrobial response against pathogenic bacteria. Clove (that contains phenolic acids such as gallic acid, flavonol glucosides, volatile phenolic oils such as eugenol, acetyl eugenol) has an application in the food 
Table 2. Types of microspheres and main characteristics

\begin{tabular}{|c|c|c|c|c|}
\hline Type & Function & Advantages & $\begin{array}{l}\text { Examples of encapsulating } \\
\text { materials }\end{array}$ & $\begin{array}{l}\text { Method for their } \\
\text { production }\end{array}$ \\
\hline Core-shell (21) & $\begin{array}{l}\text { To deposit functional } \\
\text { coatings in solid } \\
\text { substrates. }\end{array}$ & $\begin{array}{l}\text { Stability, permeability, and } \\
\text { mechanical strength. }\end{array}$ & $\begin{array}{l}\text { Electrolytes, proteins, } \\
\text { phospholipids, colloidal } \\
\text { particles. }\end{array}$ & Spray drying \\
\hline $\begin{array}{l}\text { Alginate } \\
\text { microspheres/ } \\
\text { nanospheres (26) }\end{array}$ & $\begin{array}{l}\text { External or internal } \\
\text { gelation and nanosize } \\
\text { colloidal systems. }\end{array}$ & $\begin{array}{l}\text { Biodegradability, biocompatibility, } \\
\text { nontoxicity, nonimmunogenic, } \\
\text { thermostability. }\end{array}$ & $\begin{array}{l}\text { Fragile functional ingredients } \\
\text { (i.e., enzymes, proteins, } \\
\text { carriers, EOs, extracts). }\end{array}$ & $\begin{array}{l}\text { Alginate } \\
\text { microencapsulation. }\end{array}$ \\
\hline $\begin{array}{l}\text { Cationic starch } \\
\text { nanoparticles (27) }\end{array}$ & $\begin{array}{l}\text { A paperboard in contact } \\
\text { with food and in medical } \\
\text { applications. }\end{array}$ & $\begin{array}{l}\text { Pasting, thermal, rheological } \\
\text { properties, solubility, } \\
\text { biodegradability. }\end{array}$ & $\begin{array}{l}\text { Bioactive molecules (i.e., } \\
\text { albumin, bone protein-4). }\end{array}$ & Extrusion or drying \\
\hline $\begin{array}{l}\text { Bioadhesive/ } \\
\text { Mucoadhesive } \\
\text { microspheres (28) }\end{array}$ & $\begin{array}{l}\text { Mucosal membrane } \\
\text { by using water-soluble } \\
\text { polymers. }\end{array}$ & $\begin{array}{l}\text { Prolonged contact time at the } \\
\text { application site causes intimate } \\
\text { contact with the absorption site } \\
\text { and produces better therapeutic } \\
\text { action. }\end{array}$ & $\begin{array}{l}\text { Drug delivery device adhesion } \\
\text { to the mucosal membrane } \\
\text { (buccal, ocular, rectal, nasal), } \\
\text { i.e., ranitidine. }\end{array}$ & Emulsion \\
\hline $\begin{array}{l}\text { Magnetic } \\
\text { microspheres (29) }\end{array}$ & $\begin{array}{l}\text { The magnetic targeted } \\
\text { drug delivery system. }\end{array}$ & $\begin{array}{l}\text { Noninvasive, specific, their } \\
\text { subdivision consists of; floating, } \\
\text { radioactive microspheres. }\end{array}$ & $\begin{array}{l}\text { Chitosan, dextran, monoclonal } \\
\text { antibodies. }\end{array}$ & Emulsion \\
\hline
\end{tabular}

industry for its antimicrobial activity $(30,31,33)$. Ribeiro et al showed that the elderberry extract entrapment inside microparticles of modified chitosan, sodium alginate, and gum arabic, even after 8 months. Moreover, a study by Yeşilsu and Özyurt demonstrated oxidative stability of fish oil microencapsulated by spray drying with herbal extracts $(2,34)$. Thus, the importance of the microencapsulation technique depends on the physicochemical properties of the product. Otálora et al performed the comparison between spray drying and ionic gelation on betaxanthins from Opuntia megacantha fruits, where the encapsulates showed a high total dietary fiber content and anti-radical activity. Furthermore, such added value to this yelloworange natural colorant was a biofunctional additive compared to control (35).

For the aforementioned studies, the challenges are to select the appropriate microencapsulation technique. Our study shows that the encapsulation material is an important driver, given that the physicochemical characteristics (i.e., the solubility of polymer, solvent type, concentration, $\mathrm{pH}$, a ratio of dispersed phase to continuous phase, the interaction between active principle and polymer, molecular weight) of the active ingredient to encapsulate will depend on this.

In this sense, the choice of a suitable microencapsulation technique and coating material depends on the end-use of the product and the processing conditions, e.g., for EOs, the emulsification technique complemented by another technique such as spray drying (frequently used on an industrial scale due to its performance and considerable costs) (24,25).

The extrusion is occasionally used with advantages such as protection against oxidation and prolonging the material's useful life. However, other factors must be considered, such as product compatibilities, the final product's desired mechanism, dissolution or thermal profiles and particle size (15-17,21).

Our main objective with this literature review was to investigate the herbal products relevant information with beneficial food, cosmetic and pharmaceutical industries. However, based on our findings, it is worth investigating and innovating new methods to incorporate into functional products extracted from herbs that extend their useful life through encapsulations due to this area.

\section{Conclusion}

Microencapsulation techniques are still far from being fully developed. They have not yet become a mainstream tool in the industry. However, their use as active compounds for controlled release applications is a promising alternative to solve the critical problem. These techniques focus on improving the characteristics of EOs and herbal extracts, especially from the formulation of new products to stabilize and protect the active compounds. Spray drying and coacervation are the most widely used techniques for the encapsulation of oils. Future researches must use microencapsulation technology to improve the disadvantages of natural products (low focus, volatility, oxidation, photosensitivity) and search for materials that reduce, in many cases at industrial scale, the economic cost of the encapsulation process. In this way, our review showed many of these natural products microencapsulated with diverse biological activity, prolonging their useful life, reducing costs in industries such as pharmaceuticals, food, and cosmetics by using them as antimicrobial dress, preservatives, and flavorings.

\section{Authors' contributions}

ELMA developed the article, performed the computations, wrote, and prepared and revised the corrections of the 
manuscript. At the same time, authors MVFM and CCR supervised the research and critical revision of the article. ELMA, JGSB, MVFM prepared and revised the final manuscript.

\section{Conflict of interests}

There is no conflict of interest.

\section{Ethical considerations}

Ethical issues (including plagiarism, misconduct, falsification, double publication or submission, redundancy) have been completely observed by the authors.

\section{Funding/Support}

This work was supported by the National Council of Science and Technology National Science scholarship (850039).

\section{References}

1. Munin A, Edwards-Lévy F. Encapsulation of natural polyphenolic compounds; a review. Pharmaceutics. 2011;3(4):793-829. doi: 10.3390/pharmaceutics3040793.

2. Yeşilsu AF, Özyurt G. Oxidative stability of microencapsulated fish oil with rosemary, thyme and laurel extracts: a kinetic assessment. J Food Eng. 2019;240:171-82. doi: $\quad$ 10.1016/j.jfoodeng.2018.07.021.

3. Dima C, Cotârlet M, Alexe P, Dima S. Microencapsulation of essential oil of pimento [Pimenta dioica (L) Merr.] by chitosan/k-carrageenan complex coacervation method. Innov Food Sci Emerg Technol. 2014;22:203-11. doi: 10.1016/j.ifset.2013.12.020.

4. Piletti R, Zanetti M, Jung G, de Mello JMM, Dalcanton F, Soares C, et al. Microencapsulation of garlic oil by $\beta$-cyclodextrin as a thermal protection method for antibacterial action. Mater Sci Eng C Mater Biol Appl. 2019;94:139-49. doi: 10.1016/j.msec.2018.09.037.

5. Fernandes HN, Heleno SA, Calhelha RC, Costa P, Rodrigues A, Boucherit $\mathrm{K}$, et al. Microencapsulation of Ammodaucus leucotrichus essential oil using chitosan/TPP/ vanillin chemical system. In: XXV Encontro Nacional da Sociedade Portuguesa de Química. Lisboa; 2017. Available from: https://bibliotecadigital.ipb.pt/handle/10198/15689.

6. Alagusundaram M, Madhu Sudana Chetty C, Umashankari $\mathrm{K}$, Badarinath AV, Lavanya C, Ramkanth S. Microspheres as a novel drug delivery system-a review. Int J ChemTech Res. 2009;1(3):526-34.

7. Pophof B, Stange G, Abrell L. Volatile organic compounds as signals in a plant-herbivore system: electrophysiological responses in olfactory sensilla of the moth Cactoblastis cactorum. Chem Senses. 2005;30(1):51-68. doi: 10.1093/ chemse/bji001.

8. Şahin F, Güllüce M, Daferera D, Sökmen A, Sökmen M, Polissiou M, et al. Biological activities of the essential oils and methanol extract of Origanum vulgare ssp. vulgare in the Eastern Anatolia region of Turkey. Food Control. 2004;15(7):549-57. doi: 10.1016/j.foodcont.2003.08.009.

9. Elisha IL, Botha FS, McGaw LJ, Eloff JN. The antibacterial activity of extracts of nine plant species with good activity against Escherichia coli against five other bacteria and cytotoxicity of extracts. BMC Complement Altern Med. 2017;17(1):133. doi: 10.1186/s12906-017-1645-z.

10. Jose J, Raju D, Nayak P. Microspheres-novel drug delivery carrier for plant extracts for antibacterial activity. Res J Pharm Technol. 2018;11(4):1681-4. doi: 10.5958/0974-360x.2018.00313.x.

11. Dyab AKF, Mohamed MA, Meligi NM, Mohamed SK. Encapsulation of erythromycin and bacitracin antibiotics into natural sporopollenin microcapsules: antibacterial, cytotoxicity, in vitro and in vivo release studies for enhanced bioavailability. RSC Adv. 2018;8(58):33432-44. doi: 10.1039/C8RA05499A.

12. Baranauskienė R, Žukauskaitė J, Bylaite E, Venskutonis PR. Aroma retention and flavour release of peppermint essential oil encapsulated by spray-drying into food starch based matrices. In: XIVth International Workshop on Bioencapsulation; 2006.

13. Souza ALR, Hidalgo-Chávez DW, Pontes SM, Gomes FS, Cabral LMC, Tonon RV. Microencapsulation by spray drying of a lycopene-rich tomato concentrate: characterization and stability. LWT Food Sci Technol. 2018;91:286-92. doi: 10.1016/j.lwt.2018.01.053.

14. Ahmed S, Kanchi S, Kumar G. Handbook of Biopolymers: Advances and Multifaceted Applications. CRC Press; 2018.

15. Huang YI, Cheng YH, Yu CC, Tsai TR, Cham TM. Microencapsulation of extract containing shikonin using gelatin-acacia coacervation method: a formaldehyde-free approach. Colloids Surf B Biointerfaces. 2007;58(2):290-7. doi: $\quad$ 10.1016/j.colsurfb.2007.04.013.

16. Huo X, Li W, Wang Y, Han N, Wang J, Wang N, et al. Chitosan composite microencapsulated comb-like polymeric phase change material via coacervation microencapsulation. Carbohydr Polym. 2018;200:602-10. doi: $\quad$ 10.1016/j.carbpol.2018.08.003.

17. Manaf MA, Subuki I, Jai J, Raslan R, Mustapa AN. Encapsulation of volatile citronella essential oil by coacervation: efficiency and release study. IOP Conf Ser Mater Sci Eng. 2018;358(1):012072. doi: 10.1088/1757899x/358/1/012072.

18. Eratte D, Dowling K, Barrow CJ, Adhikari B. Recent advances in the microencapsulation of omega-3 oil and probiotic bacteria through complex coacervation: a review. Trends Food Sci Technol. 2018;71:121-31. doi: 10.1016/j. tifs.2017.10.014.

19. Drioli E, Giorno L. Membrane Operations: Innovative Separations and Transformations. John Wiley \& Sons; 2009.

20. Su D, Zhong Q. Lemon oil nanoemulsions fabricated with sodium caseinate and Tween 20 using phase inversion temperature method. J Food Eng. 2016;171:214-21. doi: 10.1016/j.jfoodeng.2015.10.040.

21. Nguyen DK, Son YM, Lee NE. Hydrogel encapsulation of cells in core-shell microcapsules for cell delivery. Adv Healthc Mater. 2015;4(10):1537-44. doi: 10.1002/ adhm.201500133.

22. Park SJ, Choi W, Nam SE, Hong S, Lee JS, Lee JH. Fabrication of polyamide thin film composite reverse osmosis membranes via support-free interfacial polymerization. J Memb Sci. 2017;526:52-9. doi: 10.1016/j. memsci.2016.12.027.

23. Carvalho IT, Estevinho BN, Santos L. Application 
of microencapsulated essential oils in cosmetic and personal healthcare products - a review. Int J Cosmet Sci. 2016;38(2):109-19. doi: 10.1111/ics.12232.

24. Zuidam NJ, Shimoni E. Overview of microencapsulates for use in food products or processes and methods to make them. In: Zuidam NJ, Nedovic V, eds. Encapsulation Technologies for Active Food Ingredients and Food Processing. New York, NY: Springer; 2010. p. 3-29. doi: 10.1007/978-1-4419-1008-0_2.

25. Alvim ID, Stein MA, Koury IP, Dantas FBH, Cruz CL. Comparison between the spray drying and spray chilling microparticles contain ascorbic acid in a baked product application. LWT Food Sci Technol. 2016;65:689-94. doi: 10.1016/j.lwt.2015.08.049.

26. Lee KY, Mooney DJ. Alginate: properties and biomedical applications. Prog Polym Sci. 2012;37(1):106-26. doi: 10.1016/j.progpolymsci.2011.06.003.

27. Le Corre D, Bras J, Dufresne A. Starch nanoparticles: a review. Biomacromolecules. 2010;11(5):1139-53. doi: $10.1021 / \mathrm{bm} 901428 \mathrm{y}$.

28. Jiao Y, Pang X, Liu M, Zhang B, Li L, Zhai G. Recent progresses in bioadhesive microspheres via transmucosal administration. Colloids Surf B Biointerfaces. 2016;140:36172. doi: 10.1016/j.colsurfb.2015.12.049.

29. Zhou J, Wang Y, Ma Y, Zhang B, Zhang Q. Surface molecularly imprinted thermo-sensitive polymers based on light-weight hollow magnetic microspheres for specific recognition of BSA. Appl Surf Sci. 2019;486:265-273.

30. Cui $\mathrm{H}$, Zhao $\mathrm{C}$, Lin $\mathrm{L}$. The specific antibacterial activity of liposome-encapsulated Clove oil and its application in tofu. Food Control. 2015;56:128-34. doi: 10.1016/j. foodcont.2015.03.026.

31. Cortés-Rojas DF, deSouza CR, Oliveira WP. Clove (Syzygium aromaticum): a precious spice. Asian Pac J Trop Biomed. 2014;4(2):90-6. doi: 10.1016/s2221-1691(14)60215-x.

32. Tiwari BK, Valdramidis VP, O'Donnell CP, Muthukumarappan K, Bourke P, Cullen PJ. Application of natural antimicrobials for food preservation. J Agric Food Chem. 2009;57(14):5987-6000. doi: 10.1021/jf900668n.

33. Khan I, Khan U, Khan K, Nawaz MA, Khan NA, Ali F. In vitro anti-pseudomonal potential of Juglans regia and Otostegia limbata leaves extract against planktonic and biofilm form of Pseudomonas aeruginosa. Pak J Bot. 2018;50(2):827-33.

34. Ribeiro AM, Estevinho BN, Rocha F. Spray drying encapsulation of elderberry extract and evaluating the release and stability of phenolic compounds in encapsulated powders. Food Bioproc Tech. 2019;12(8):1381-94. doi: 10.1007/s11947-019-02304-z.

35. Otálora MC, Carriazo JG, Osorio C, Nazareno MA. Encapsulation of cactus (Opuntia megacantha) betaxanthins by ionic gelation and spray drying: a comparative study. Food Res Int. 2018;111:423-30. doi: 10.1016/j. foodres.2018.05.058. 